\title{
Papular elastorrhexis: clinical perspectives
}

This article was published in the following Dove Press journal:

Clinical, Cosmetic and Investigational Dermatology

\section{Engin Sezer \\ Emel Öztürk Durmaz \\ Sedef Șahin \\ Department of Dermatology, Acibadem University School of Medicine, Istanbul, Turkey}

Correspondence: Engin Sezer Department of Dermatology, Acibadem University School of Medicine, Buyukdere Caddesi, No: 40, Istanbul, 34457, Turkey Tel +902I2304 4626

Fax +90212304 4440

Email engin.sezer@acibadem.com.tr

\begin{abstract}
First described by Bordas in 1987, papular elastorrhexis (PE) is a rare elastic fiber disorder of the skin characterized by multiple, discrete, asymptomatic, firm, nonfollicular, monomorphous, 1-5 mm, circumscribed, hypopigmented, oval to round papules, symmetrically distributed on the chest, abdomen, back, shoulders, arms, and thighs. The onset of the condition is usually in the first or second decade of life. PE appears to be an exceedingly rare entity, with 33 cases reported in the literature until now. However, the disorder might be underestimated probably because of its subtlety, asymptomatic course, and benign nature of clinical alterations, which can easily be confused with other dermatoses such as acne scars. Clinical and histopathological differential diagnosis of PE is broad and includes papular acne scars, eruptive collagenoma, disseminated lenticular dermatofibrosis (as a component of Buschke-Ollendorff syndrome), white fibrous papulosis of the neck, pseudoxanthoma elasticum, pseudoxanthoma elasticum-like papillary dermal elastolysis, middermal elastolysis, and perifollicular elastolysis. Treatment of PE is a matter of debate and no reliable curative option exists.
\end{abstract}

Keywords: papular elastorrhexis, elastic fibers, connective tissue

\section{Introduction}

Papular elastorrhexis (PE) is a rare disorder clinically characterized by asymptomatic papules that show fragmentation of dermal elastic fibers on biopsy. ${ }^{1}$ The lesions present as multiple, nonfollicular, hypopigmented papules, $1-5 \mathrm{~mm}$ in size located mainly on the chest, back, and abdomen. The onset is usually within the first or second decade of life. Histopathological examination reveals focal fragmentation and decrease of elastic fibers in the dermis. Treatment of this entity is a matter of debate since no effective treatment option exists in the literature. However, definitive diagnosis of PE and reassurance of the patients regarding the benign nature of this entity are important. In this manuscript, epidemiological, clinical, histopathological portrait and differential diagnosis of PE is discussed using a PubMed search.

\section{History}

PE was initially described in 1987 by Bordas et $\mathrm{al}^{2}$ as a variant of nevus anelasticus. The clinical presentation in the original report was characterized by several small yellowish papules on the trunk with a reduction and fragmentation of the elastic fibers histopathologically. In 1988, Sears et $\mathrm{al}^{3}$ presented two additional cases and considered that the entity may represent a variant of connective tissue nevus. 


\section{Epidemiology}

Up to now, 33 cases of PE have been reported in the English literature. ${ }^{4-9}$ The rarity of this disease is probably due to its subtlety, asymptomatic course, and benign nature of clinical alterations, which can easily be confused with other dermatoses such as acne scars. ${ }^{7,10}$ The condition has a predilection for the female gender, with 20 female and 13 male patients reported so far. ${ }^{9}$ The onset is usually in the first or second decade of life. ${ }^{1,11}$ However, a single case has been reported in a 45 -year-old woman. ${ }^{1}$

\section{Etiology and pathogenesis}

The etiopathogenesis is skeptical. ${ }^{1}$ Except for an isolated case of familial clustering, most of the cases reported hitherto are sporadic and acquired. ${ }^{1,4,10}$ There is typically no history of antecedent trauma, local inflammation, infection, or acne. ${ }^{1,5,6}$

The nosological classification of $\mathrm{PE}$ is also controversial. ${ }^{4}$ Some authors consider familial PE as an abortive incomplete variant of Buschke-Ollendorff syndrome (BOS) without associated osteopoikilosis. ${ }^{3,12} \mathrm{BOS}$ is an autosomal dominant disease characterized by disseminated connective tissue nevi (usually elastomas) or osteopoikilosis or both and is associated with mutations in the LEMD3 gene. ${ }^{1,5,16}$ In one study, LEMD3 mutations have not been identified in two patients with $\mathrm{PE}$, and the authors concluded that $\mathrm{PE}$ does not belong to the genomic spectrum of BOS. ${ }^{4}$ Thus, some authors believe that PE is a unique entity distinct from BOS. ${ }^{46,8}$ Nevertheless, $\mathrm{PE}$ is a very rarely encountered disorder, and the debate as to whether it is a variant of BOS or a distinct entity continues. ${ }^{4}$

A single case report of sudden onset of PE in a 13-yearold child during immunological recovery from HIV infection has been reported. The authors hypothesized that the sudden immunological recovery may trigger an imbalance between elastin anabolic mechanisms and T-cell upregulated catabolic pathways, which could have caused the marked loss and fragmentation of elastic tissue. ${ }^{13}$

A recent electron microscopic study in PE highlighted the diminution and degeneration of fibroblasts and elastic tissue as well as swollen collagen bundles, suggesting that the elastic tissue disorder may result from disorganized fibroblasts. ${ }^{14}$

Some authors consider PE as a reparative process based on clinical and histopathological findings. ${ }^{3}$ Reports of PE localized to sites of antecedent trauma may support this theory. ${ }^{15}$

\section{Clinics}

Clinically, the disorder is characterized by multiple, discrete, asymptomatic, firm, nonfollicular, monomorphous,
1-5 mm, circumscribed, oval to round papules. ${ }^{1,5,12}$ The lesions have no tendency to group or merge into plaques. ${ }^{5,12}$ They are typically skin colored or creamy, although hypochromic variants have been reported. ${ }^{3,7,8}$ The lesions are symmetrically distributed on the chest, abdomen, back, shoulders, arms, and thighs. ${ }^{1,5}$ There have been anecdotal reports demonstrating uncommon locations such as the armpits, neck, nape, occipitocervical, and mandibular regions. ${ }^{5,7}$ A solitary variant has been reported. ${ }^{9}$ The lesion was described as a single, well-defined, soft, hypopigmented, nonfollicular papule of $0.5 \mathrm{~cm}$ diameter with a wrinkled surface in a 16-year-old boy with diagnostic histopathological features. An unusual case of several flesh-colored papules on the wrist of a 54-year-old woman, corresponding to an intravenous infusion drug site, has also been described. ${ }^{15}$ Facial PE and PE developing in an eruptive manner have been described by our group. ${ }^{1,5,16}$ So far, there has been no report of systemic affection. ${ }^{1,5,12}$

\section{Histopathology}

Histopathological examination displays substantial focal fragmentation and decrease or partial loss of elastic fibers in the reticular dermis, which results in a speckled appearance. ${ }^{1,10}$ A slight perivascular lymphohistiocytic superficial and deep dermal inflammation might be observed..$^{1,10}$ There might be focal areas of fibrosis in the middermis, where collagen bundles may be thickened, homogenized, and condensed. ${ }^{1,4,5}$ Mucin deposition around the abnormal elastic fibers has rarely been documented. ${ }^{17}$

Electron microscopy may reveal an absolute reduction of elastic tissue, with a relative increase in the fibrillar component of elastic fibers as compared with normal fibers. ${ }^{1,7}$

\section{Prognosis}

After a gradual evolution phase over the years, the lesions are relatively stable, with no tendency for spontaneous resolution. $^{7}$

\section{Differential diagnosis}

The list of differential diagnostic considerations embraces nevus anelasticus, papular acne scars, eruptive collagenoma, disseminated lenticular dermatofibrosis (BOS), white fibrous papulosis of the neck, pseudoxanthoma elasticum, pseudoxanthoma elasticum-like papillary dermal elastolysis, middermal elastolysis, and perifollicular elastolysis..$^{1,6-8}$

Table 1 summarizes the key epidemiological, clinical, and histopathological differential diagnosis of PE. 
Table I Differential diagnosis of papular elastorrhexis

\begin{tabular}{|c|c|c|c|c|}
\hline Entity & Age & Clinics & Histopathology & Associations \\
\hline Papular elastorrhexis & $\begin{array}{l}\text { First to second } \\
\text { decades }\end{array}$ & $\begin{array}{l}\text { Multiple, discrete, nonfollicular, } \\
\text { hypopigmented, I-5 mm papules } \\
\text { on the chest, abdomen, and back }\end{array}$ & $\begin{array}{l}\text { Focal fragmentation decrease or loss of } \\
\text { elastic fibers } \\
\text { Thickened collagen bundles } \\
\text { Perivascular inflammation }\end{array}$ & None \\
\hline Nevus anelasticus & Few cases reported & $\begin{array}{l}\text { Perifollicular papules with a pink } \\
\text { to red hue } \\
\text { Confluent plaques }\end{array}$ & $\begin{array}{l}\text { Fragmentation (less prominent) or loss } \\
\text { (more prominent) of elastic fibers } \\
\text { Minimal or no changes in collagen } \\
\text { bundles }\end{array}$ & None \\
\hline Acne scars & Second decade & $\begin{array}{l}\text { Asymptomatic, hypopigmented } \\
\text { papules on the upper back, } \\
\text { shoulder, and chest }\end{array}$ & $\begin{array}{l}\text { Scarring with fibroblastic proliferation } \\
\text { and elastic tissue alteration around } \\
\text { pilosebaceous unit }\end{array}$ & Acne \\
\hline Eruptive collagenoma & $\begin{array}{l}\text { First to second } \\
\text { decades }\end{array}$ & $\begin{array}{l}\text { Multiple, white or flesh-colored, } \\
2-5 \mathrm{~mm} \text { papules on trunk }\end{array}$ & $\begin{array}{l}\text { Prominent thickened, swollen, and } \\
\text { homogenized collagen bundles with } \\
\text { reduced elastic fibers }\end{array}$ & $\begin{array}{l}\text { Down syndrome } \\
\text { MEN type I }\end{array}$ \\
\hline $\begin{array}{l}\text { Dermatofibrosis } \\
\text { lenticularis (BOS) }\end{array}$ & Childhood & $\begin{array}{l}\text { Asymmetrical, skin-colored } \\
\text { papules and plaques on the trunk } \\
\text { and extremities }\end{array}$ & $\begin{array}{l}\text { Thickened and branched elastic fibers } \\
\text { encircle the collagen bundles }\end{array}$ & Osteopoikilosis \\
\hline $\begin{array}{l}\text { White fibrous } \\
\text { papulosis of the neck }\end{array}$ & $\begin{array}{l}\text { Fourth to eighth } \\
\text { decades }\end{array}$ & $\begin{array}{l}\text { Symmetrical, } 2-3 \mathrm{~mm} \text {, white to } \\
\text { pale papules restricted to neck } \\
\text { and upper sternal region }\end{array}$ & $\begin{array}{l}\text { Marked fibrosis and altered elastic tissue } \\
\text { in the upper dermis }\end{array}$ & None \\
\hline $\begin{array}{l}\text { Pseudoxanthoma } \\
\text { elasticum }\end{array}$ & $\begin{array}{l}\text { First to second } \\
\text { decades }\end{array}$ & $\begin{array}{l}\text { Small, yellowish papules on the } \\
\text { neck, axilla, and groins }\end{array}$ & $\begin{array}{l}\text { Basophilic thickened elastic fibers } \\
\text { identified on H\&E stains }\end{array}$ & $\begin{array}{l}\text { Eye and } \\
\text { cardiovascular } \\
\text { involvement }\end{array}$ \\
\hline $\begin{array}{l}\text { Pseudoxanthoma } \\
\text { elasticum-like papillary } \\
\text { dermal elastolysis }\end{array}$ & $\begin{array}{l}\text { Sixth to eighth } \\
\text { decades }\end{array}$ & $\begin{array}{l}\text { Asymptomatic or pruritic, yellow } \\
\text { or skin-colored, } 2-3 \mathrm{~mm} \text { papules } \\
\text { on the lateral and posterior } \\
\text { aspects of the neck, axilla, and } \\
\text { arms }\end{array}$ & $\begin{array}{l}\text { Bandlike loss of elastic fibers restricted } \\
\text { to papillary dermis }\end{array}$ & None \\
\hline Middermal elastolysis & $\begin{array}{l}\text { Third to fifth } \\
\text { decades }\end{array}$ & $\begin{array}{l}\text { Plaques revealing fine wrinkling on } \\
\text { the trunk, neck, and arm }\end{array}$ & $\begin{array}{l}\text { Loss of elastic tissue restricted to } \\
\text { middermis }\end{array}$ & $\begin{array}{l}\text { Urticaria } \\
\text { Granuloma } \\
\text { annulare }\end{array}$ \\
\hline Perifollicular elastolysis & $\begin{array}{l}\text { A few cases } \\
\text { reported }\end{array}$ & $\begin{array}{l}\text { Gray to white papules on the } \\
\text { head, upper trunk, and arms }\end{array}$ & $\begin{array}{l}\text { Elastic fiber alteration centered around } \\
\text { hair follicles }\end{array}$ & $\begin{array}{l}\text { Behçet's disease } \\
\text { Atopic dermatitis }\end{array}$ \\
\hline
\end{tabular}

Abbreviations: BOS, Buschke-Ollendorff syndrome; MEN, multiple endocrine neoplasia.

\section{Treatment}

Affected patients should be reassured about the benign nature of the condition. ${ }^{7}$ There is no reliable curative treatment for papular elastorrhexis. ${ }^{1,5}$ One anecdotal report showed improvement after intralesional injection of triamcinolone. ${ }^{1}$ Oral antibiotics, oral isotretinoin, topical tretinoin, and benzoyl peroxide usually have futile outcomes. ${ }^{1,3,11}$

\section{Conclusion}

PE is a rare elastic fiber disorder of the skin with a predilection for the female gender, and its onset is in the first or second decade of life. The disorder is characterized by multiple, discrete, asymptomatic, nonfollicular, monomorphous, hypopigmented, oval to round papules symmetrically distributed on the chest, abdomen, back, shoulders, arms, and thighs. The ultimate diagnosis of this rare entity is important, since a broad list of differential diagnostic considerations exists. Thorough knowledge of its epidemiological, clinical, and histopathological features and exclusion of associated systemic disorders are essential to reach the final diagnosis. Then, reassurance of the patients will be all that is required.

The limitation of this study is the absence of metaanalysis, because of the rarity of the condition and lack of clinical cohort studies to obtain a meta-analysis. Thus, the information presented herein is based on case presentations of the disorder, derived from a complete PubMed search.

\section{Disclosure}

The authors report no conflicts of interest in this work. 


\section{References}

1. Lewis KG, Bercovitch L, Dill SW, Robinson-Bostom L. Acquired disorders of elastic tissue: Part II. decreased elastic tissue. J Am Acad Dermatol. 2004;51(2):165-185.

2. Bordas X, Ferrándiz C, Ribera M, Galofré E. Papular elastorrhexis: a variety of nevus anelasticus? Arch Dermatol. 1987;123(4):433-434.

3. Sears JK, Stone MS, Argenyi Z. Papular elastorrhexis: a variant of connective tissue nevus. Case reports and review of the literature. J Am Acad Dermatol. 1988;19(2 Pt 2):409-414.

4. Cañueto J, Román C, Á S-B, et al. and Buschke-Ollendorff syndrome are different entities. J Am Acad Dermatol. 2011;65(1):7-9.

5. Tan C, Zhu WY, Min ZS. Papular elastorrhexis located on occipitocervical and mandibular regions. Eur J Dermatol. 2009;19(4):399-400.

6. Flores PB, Cuevas J, Sánchez C, de Eusebio E, Vergara A. Papular elastorrhexis: an acquired disorder of elastic tissue. Eur J Dermatol. 2010;20(4):525-526.

7. Thomé EP, Steglich RB, Meotti CD, Schwartz J, Boff AL. Case for diagnosis. An Bras Dermatol. 2012;87(4):651-653.

8. Choi Y, Jin SY, Lee JH, Kwon HB, Lee AY, Lee SH. Papular elastorrhexis: a case and differential diagnosis. Ann Dermatol. 2011;23(Suppl 1): S53-S56.

9. Bhushan P, Thatte S, Singh A. Solitary lesion in papular elastorrhexis: A diagnostic challenge. Indian Dermatol Online J. 2017;8(1):53-55.
10. del Pozo J, Martinez W, Sacristan F, Fernandez-Jorge B, Fonseca E, Elastorrhexis P. a distinctive entity? Am J Dermatopathol. 2008;30(2):188-190.

11. Ryder HF, Antaya RJ. Nevus anelasticus, papular elastorrhexis, and eruptive collagenoma: clinically similar entities with focal absence of elastic fibers in childhood. Pediatr Dermatol. 2005;22(2):153-157.

12. Choonhakarn C, Jirarattanapochai K. Papular elastorrhexis: a distinct variant of connective tissue nevi or an incomplete form of BuschkeOllendorff syndrome? Clin Exp Dermatol. 2002;27(6):454-457.

13. Rodríguez-Lomba E, Molina-López I, Parra-Blanco V, Suárez-Fernández R, Campos-Domínguez M. Sudden Onset of Papular Elastorrhexis After Immunologic Recovery in a Boy with Human Immunodeficiency Virus. Pediatr Dermatol. 2016;33(6):e356-e357.

14. Li SJ, Peng J, Yang PP, Sheng P, Fan YM. Immunopathological and ultrastructural features in a case of papular elastorrhexis. J Dtsch Dermatol Ges. 2017;15(2):212-214.

15. Kim YH, Lee JH, Lee JY, Park YM. Papular elastorrhexis localized to the wrist, the intravenous infusion drip site. Ann Maxillofac Surg. 2016;6(1):148-149

16. Şahin S, Durmaz EÖ, Sezer E, Çetin ED. Eruptive papular elastorrhexis of the face and scalp. J Am Acad Dermatol. 2013;69(5):e251-e252.

17. Pajot C, Le Clec'h C, Hoareau F, Croue A, Verret JL. Two cases of papular elastorrhexis. Ann Dermatol Venereol. 2008;135(11):757-761.
Clinical, Cosmetic and Investigational Dermatology

\section{Publish your work in this journal}

Clinical, Cosmetic and Investigational Dermatology is an international, peer-reviewed, open access, online journal that focuses on the latest clinical and experimental research in all aspects of skin disease and cosmetic interventions. This journal is included on PubMed. The manuscript management system is completely online

\section{Dovepress}

and includes a very quick and fair peer-review system, which is all easy to use. Visit http://www.dovepress.com/testimonials.php to read rea quotes from published authors 